\title{
PENGARUH TRANSAKSI PIHAK-PIHAK ISTIMEWA TERHADAP KINERJA KEUANGAN PERUSAHAAN
}

\author{
Fransiska \\ Jenjang Sri Lestari
}

\begin{abstract}
Prgram Studi Akuntansi Fakultas Ekonomi Universitas Atma Jaya Yogyakarta Jalan Babarsari 43-44, Yogyakarta
\end{abstract}

\begin{abstract}
Abstrak
Penelitian ini bertujuan untuk menganalisis apakah terdapat pengaruh transaksi pihak-pihak istimewa yang diukur dengan penjualan kepada pihak-pihak istimewa dan pembelian dari pihak-pihak istimewa terhadap kinerja keuangan yang diukur dengan Return On Asset (ROA). Sampel yang digunakan dalam penelitian ini adalah sebanyak 224 perusahaan manufaktur yang terdaftar di BEI, dengan periode penelitian 2010-2012. Pengambilan sampel menggunakan metode purposive sampling. Data yang digunakan merupakan data sekunder yang diperoleh dari web BEI yaitu melalui idx.co.id.

Hasil penelitian yang dilakukan menunjukkan bahwa: (1) penjualan kepada pihak-pihak istimewa tidak berpengaruh signifikan terhadap kinerja keuangan perusahaan, (2) pembelian dari pihak-pihak istimewa berpengaruh signifikan terhadap kinerja keuangan perusahaan.
\end{abstract}

\section{Kata kunci : Transaksi Pihak-Pihak Istimewa, Kinerja Keuangan, Pihak Berelasi, Pihak Istimewa, Return On Asset, Related Party}

\section{A. Pendahuluan}

Perusahaan melakukan transaksi dengan pihak yang mempunyai relasi dengan perusahaan. Transaksi inilah yang dikenal dengan transaksi pihak-pihak istimewa. Di Indonesia, perlakuan akuntansi terhadap transaksi pihak-pihak istimewa telah diatur dalam PSAK No. 7 (revisi 2009) tentang Pengungkapan Pihak-Pihak yang Mempunyai Hubungan Istimewa. Dalam PSAK No. 7 (revisi 2009) disebutkan bahwa pihak-pihak yang dianggap mempunyai hubungan istimewa bila satu pihak mempunyai kemampuan untuk mengendalikan pihak lain atau mempunyai pengaruh signifikan atas pihak lain dalam mengambil keputusan keuangan dan operasional.

Terdapat dua sudut pandang mengenai pengaruh transaksi pihak-pihak istimewa terhadap kinerja keuangan perusahaan yaitu: transaksi pihak-pihak istimewa dapat meningkatkan efisiensi operasional perusahaan, dan transaksi pihak-pihak istimewa juga dapat bersifat merugikan. (Keng et al., 2010). Penelitian Chen et al. (2009) menemukan bahwa ketika suatu perusahaan dikendalikan oleh perusahaan yang mengendalikan maka kinerja keuangan perusahaan yang dikendalikan akan buruk.

Penelitian ini menggunakan transaksi pihak-pihak istimewa yang diukur dengan menggunakan penjualan kepada pihak-pihak istimewa dan pembelian dari pihak-pihak istimewa. Penggunaan dua variabel ini karena perusahaan dalam 
melakukan kegiatan operasinya tidak terlepas dari penjualan persediaan dan pembelian bahan baku. Penelitian ini hanya berfokus pada kinerja keuangan perusahaan karena SAK per 1 Juni 2012 tentang Kerangka Dasar Penyusunan dan Penyajian Laporan Keuangan mengatakan bahwa penghasilan bersih (laba) sering kali digunakan sebagai ukuran kinerja atau sebagai dasar bagi ukuran yang lain seperti imbal hasil investasi (return on investment) atau laba per saham (earning per share. Penelitian ini mengambil perusahaan manufaktur sebagai sampel penelitian karena aktivitas utama perusahaan manufaktur adalah memproduksi barang sampai pada proses akhir ketika barang dijual. Alasan lain memilih perusahaan manufaktur disebabkan karena jumlah perusahaan manufaktur lebih banyak dibandingkan jumlah perusahaan non manufaktur.

Rumusan masalah dalam penelitian ini yaitu:

1. Apakah penjualan dengan pihak-pihak istimewa berpengaruh terhadap kinerja keuangan perusahaan?

2. Apakah pembelian dari pihak-pihak istimewa berpengaruh terhadap kinerja keuangan perusahaan?

Tujuan dari penelitian ini yaitu untuk memberikan bukti secara empiris bahwa terdapat pengaruh penjualan kepada pihak-pihak istimewa, dan pembelian dari pihak-pihak istimewa terhadap kinerja keuangan perusahaan.

\section{B. LANDASAN TEORI DAN PENGEMBANGAN HIPOTESIS Pihak-Pihak yang Mempunyai Hubungan Istimewa}

Pernyataan Standar Akuntansi Keuangan (PSAK) No. 7 (revisi 2009) tentang Pengungkapan Pihak-Pihak yang Mempunyai Hubungan Istimewa mengatur tentang pihak-pihak yang mempunyai hubungan istimewa. Istilah berikut yang digunakan dalam pernyataan ini (PSAK No. 7 (revisi 2009) paragraf 09) :

Anggota keluarga dekat dari individu adalah anggota keluarga yang mungkin mempengaruhi, atau dipengaruhi oleh, orang dalam hubungan mereka dengan entitas. Mereka dapat termasuk:

(a) pasangan hidup dan anak dari individu;

(b) anak dari pasangan hidup individu; dan

(c) tanggungan dari individu atau pasangan hidup individu.

Anggota manajemen kunci adalah orang-orang yang mempunyai kewenangan dan tanggung jawab untuk merencanakan, memimpin dan mengendalikan aktivitas entitas, secara langsung atau tidak langsung, termasuk direktur dan komisaris (baik eksekutif maupun tidak) dari entitas.

Entitas pemerintah yang mempunyai hubungan istimewa adalah entitas yang dikendalikan, dikendalikan bersama, atau dipengaruhi secara signifikan oleh pemerintah.

Imbalan kerja adalah seluruh bentuk imbalan yang dibayar, terutang atau diberikan oleh entitas, atau untuk kepentingan entitas, atas imbalan jasa yang diberikan kepada entitas. Hal ini juga mencakup imbalan yang dibayarkan untuk kepentingan entitas induk terkait dengan entitas. Kompensasi meliputi: 
(a) imbalan kerja jangka pendek, seperti upah, gaji dan kontribusi jaminan sosial, cuti tahunan dan cuti sakit yang dibayar, bagi hasil dan bonus (jika dibayarkan dalam waktu dua belas bulan setelah akhir periode) dan imbalan non keuangan (seperti perawatan kesehatan, perumahan, mobil dan barang atau jasa gratis atau disubsidi) bagi karyawan saat ini;

(b) imbalan pasca-kerja seperti pensiun, manfaat pensiun lain, asuransi jiwa pasca-kerja dan perawatan medis pasca-kerja;

(c) imbalan kerja jangka panjang lainnya, termasuk cuti masa kerja panjang (long-service leave or sabbatical leave), jubilee (perayaan masa kerja panjang) atau imbalan masa kerja panjang lainnya, imbalan cacat jangka panjang dan, jika tidak dibayar sepenuhnya dalam waktu dua belas bulan setelah akhir periode, bagi hasil, bonus dan kompensasi yang ditangguhkan;

(d) pesangon pemutusan kontrak kerja; dan

(e) pembayaran berbasis saham.

Kompensasi termasuk seluruh imbalan kerja (sebagaimana didefinisikan dalam PSAK 24 (revisi 2004): Imbalan Kerja) termasuk imbalan kerja yang berlaku pada PSAK 53: Akuntansi Pembayaran Berbasis Saham.

Pemerintah merujuk kepada pemerintahan, instansi pemerintah dan badan yang serupa baik lokal, nasional maupun internasional.

Pengaruh signifikan adalah kekuasaan untuk berpartisipasi dalam keputusan kebijakan keuangan dan operasi dari suatu entitas, tetapi tidak mengendalikan kebijakan tersebut. Pengaruh signifikan dapat diperoleh dengan kepemilikan saham, anggaran dasar atau perjanjian.

Pengendalian adalah kekuasaan untuk mengatur kebijakan keuangan dan operasi dari suatu entitas sehingga memperoleh manfaat dari aktivitas tersebut.

Pengendalian bersama adalah persetujuan kontraktual untuk berbagi pengendalian terhadap suatu aktivitas ekonomi.

Pihak-pihak yang mempunyai hubungan istimewa adalah orang atau entitas yang terkait dengan entitas tertentu dalam menyiapkan laporan keuangannya (dalam Pernyataan ini dirujuk sebagai "entitas pelapor").

(a) Orang atau anggota keluarga terdekat terkait entitas pelapor jika orang tersebut:

(i) memiliki pengendalian atau pengendalian bersama atas entitas pelapor;

(ii) memiliki pengaruh signifikan terhadap entitas pelapor; atau

(iii) personal manajemen kunci entitas pelapor atau entitas induk entitas pelapor

(b) Suatu entitas terkait dengan entitas pelapor jika memenuhi salah satu hal berikut;

(i) Entitas dan entitas pelapor adalah anggota dari kelompok usaha yang sama (artinya entitas induk, entitas anak dan entitas anak berikutnya terkait dengan entitas lain.

(ii) Satu entitas adalah entitas asosiasi atau ventura bersama bagi entitas lain (atau entitas asosiasi atau ventura bersama yang merupakan anggota suatu kelompok usaha, dimana entitas lain tersebut adalah anggotanya. 
(iii) Kedua entitas tersebut adalah ventura bersama dari pihak ketiga yang sama.

(iv) Satu entitas adalah ventura bersama dari entitas ketiga dan entitas yang lain adalah entitas asosiasi dari entitas ketiga.

(v) Entitas tersebut adalah suatu program imbalan pasca kerja untuk imbalan kerja dari salah satu entitas pelapor atau entitas yang terkait dengan entitas pelapor. Jika entitas pelapor adalah entitas yang menyelenggarakan program tersebut, entitas sponsor juga terkait dengan entitas pelapor.

(vi) Entitas yang dikendalikan atau dikendalikan bersama oleh orang yang diidentifikasi dalam butir (a).

(vii) Orang yang diidentifikasi dalam butir (a) (i) memiliki pengaruh signifikan terhadap entitas atau anggota menejemen kunci entitas (atau entitas induk dari entitas).

Transaksi pihak yang mempunyai hubungan istimewa adalah suatu pengalihan sumber daya, jasa atau kewajiban antara entitas pelapor dengan pihak-pihak yang mempunyai hubungan istimewa, terlepas apakah ada harga yang dibebankan

\section{Kinerja Keuangan}

Menurut Horne (1998: 9) kinerja keuangan adalah ukuran prestasi perusahaan maka keuntungan merupakan salah satu alat yang digunakan oleh manajer. Kinerja keuangan juga akan memberikan gambaran efisiensi atas penggunaaan dana mengenai hasil akan memperoleh keuntungan yang dapat dilihat setelah membandingkan pendapatan bersih setelah pajak dengan aset perusahaan. SAK per 1 Juni 2012 tentang Kerangka Dasar Penyusunan dan Penyajian Laporan Keuangan paragraf 17 menyebutkan bahwa informasi kinerja perusahaan terutama profitabilitas diperlukan untuk menilai perubahan potensial sumber daya ekonomi yang mungkin dikendalikan di masa depan. Informasi fluktuasi kinerja ini adalah penting dalam hubungan ini. Informasi kinerja keuangan bermanfaat untuk memprediksi kapasitas perusahaan dalam menghasilkan arus kas dari sumber daya yang ada. Di samping itu, informasi tersebut juga berguna dalam perumusan pertimbangan tentang efektivitas perusahaan dalam memanfaatkan tambahan sumber daya.

Kinerja keuangan perusahaan dapat dihitung dengan menggunakan informasiinformasi keuangan yang terdapat dalam laporan keuangan. Laporan keuangan akan memberikan informasi mengenai profitabilitas, risiko, timing aliran kas, yang kesemuanya akan mempengaruhi harapan pihak-pihak yang berkepentingan. (Hanafi, 2003: 71). Laporan keuangan diharapkan dapat memberikan informasi mengenai kinerja keuangan perusahaan dalam suatu periode dan juga informasi mengenai pertanggungjawaban kepengurusan manajemen kepada pemilik. (SFAC No. 1, 1978: 2). SFAC No. 1 paragraf 43 menyatakan bahwa fokus utama dari pelaporan keuangan adalah informasi mengenai kinerja perusahaan yang disediakan dengan mengukur laba dan komponennya. Investor, kreditur, dan pihak lain yang berkepentingan dengan penilaian prospek untuk arus kas bersih perusahaan lebih tertarik pada informasi tersebut. Perhatian mereka terhadap arus kas masa depan perusahaan dan kemampuannya untuk menghasilkan arus kas 
yang menguntungkan terutama mengarah kepada ketertarikan informasi tentang laba daripada informasi mengenai arus kas itu sendiri. Laporan keuangan yang hanya menunjukkan penerimaan dan pengeluaran kas selama periode singkat, seperti satu tahun, tidak cukup untuk menunjukkan kinerja sebuah perusahaan berhasil atau tidak.

SAK per 1 Juni 2012 tentang Kerangka Dasar Penyusunan dan Penyajian Laporan Keuangan paragraf 69 menyatakan bahwa penghasilan bersih (laba) sering kali digunakan sebagai ukuran kinerja atau sebagi dasar bagi ukuran yang lain seperti imbal hasil investasi (return on investment) atau laba per saham (earning per share). SFAC No. 1 paragraf 47 menyatakan bahwa investor, kreditur, dan pihak lainnya menggunakan laba yang dilaporkan dan informasi mengenai komponen laba untuk beragam cara dan beragam tujuan dalam menilai prospek mereka untuk aliran kas dari investasi dan atau pinjaman kepada perusahaan. Sebagai contoh, mereka menggunakan informasi laba untuk membantu mereka dalam (a) mengevaluasi kinerja manajer, (b) mengestimasi "earning power" atau jumlah lainnya yang mereka anggap sebagai "perwakilan" dari kemampuan laba jangka panjang perusahaan, (c) memprediksi laba masa depan, atau (d) menilai risiko investasi dalam atau pinjaman perusahaan.

Pelaporan keuangan diharapkan menyediakan informasi mengenai kinerja keuangan perusahaan selama satu periode dan mengenai bagaimana manajemen sebuah perusahaan menjalankan tanggung jawab nya terhadap pemilik perusahaan. (SFAC No. 1, 1987: 2) Manajemen bertanggung jawab kepada pemilik bukan hanya pada pengamanan sumber daya perusahaan tetapi juga pada pengggunaan sumber daya yang efisien dan menguntungkan. Berdasarkan dari penjelasan tersebut, maka penelitian ini menggunakan Return On Asset (ROA) dalam mengukur kinerja keuangan perusahaan. Return On Asset (ROA) atau yang sering disebut sebagai Return On Investment (ROI) digunakan untuk mengukur kemampuan perusahaan menghasilkan laba bersih berdasarkan tingkat aset yang tertentu. (Hanafi, 2003: 86). Rasio ROA yang tinggi menunjukkan bahwa manajemen telah secara efisien menggunakan aset mereka untuk menghasilkan laba bersih. Rasio ROA yang rendah menunjukkan bahwa manajemen dalam menghasilkan laba bersih belum bisa secara efisien dalam menggunakan aset perusahaan.

\section{PENGEMBANGAN HIPOTESIS}

PSAK No. 7 (revisi 2009) paragraf 06 menjelaskan bahwa suatu hubungan dengan pihak-pihak yang mempunyai hubungan istimewa dapat berpengaruh terhadap laba atau rugi dan posisi keuangan entitas. Pihak-pihak yang mempunyai hubungan istimewa dapat menyepakati transaksi di mana pihak-pihak yang tidak mempunyai hubungan istimewa tidak dapat melakukannya. Misalnya, entitas yang menjual barang kepada entitas induknya pada harga perolehan, mungkin tidak menjual dengan persyaratan tersebut kepada pelanggan lain. Selain itu, transaksi antara pihak-pihak yang mempunyai hubungan istimewa mungkin tidak dilakukan dalam jumlah yang sama, seperti dengan pihak-pihak yang tidak mempunyai hubungan istimewa. 
Terdapat dua sudut pandang tentang pengaruh transaksi pihak-pihak istimewa terhadap kinerja keuangan perusahaan. Pandangan pertama transaksi pihak-pihak istimewa dapat dilakukan untuk mengurangi biaya transaksi dan menciptakan efisiensi. Pandangan kedua, transaksi pihak-pihak istimewa dapat bersifat merugikan bagi perusahaan yang dikendalikan. (Chen et al., 2009)

Perusahaan lebih efisien menjual kepada pihak-pihak istimewa karena dengan melakukan transaksi ini, perusahaan dapat melakukan penghematan terhadap biaya transaksi. Perusahaan dapat mengurangi biaya transaksi sehingga beban perusahaan menjadi rendah sehingga laba perusahaan menjadi naik yang kemudian diikuti dengan kinerja keuangan perusahaan yang baik. Hal ini akan berbeda ketika perusahaan menjual barangnya kepada pihak luar. Perusahaan harus mengeluarkan biaya lebih jika transaksi penjualan dilakukan dengan pihak yang bukan pihak istimewa. Perusahaan tidak dapat mengurangi biaya transaksi sehingga laba perusahaan akan rendah dan kinerja keuangan perusahaan juga rendah.

Transaksi pihak-pihak istimewa juga dapat dilakukan dengan pihak yang mempunyai afiliasi terhadap perusahaan. Perusahaan melakukan kontrak penjualan jangka panjang dengan perusahaan afiliasi untuk menghindari risiko. Risiko yang dihadapi perusahaan bisa saja berupa turunnya harga di masa depan ketika perusahaan akan menjual produknya. Hal seperti ini dapat berakibat pada turunnya pendapatan dan laba perusahaan. Perusahaan yang telah melakukan kontrak penjualan jangka panjang akan menerima pendapatan sebesar harga yang telah disetujui didalam kontrak, sehingga perusahaan tidak mengalami rugi akibat ketidakpastian yang terjadi di masa depan.

Perusahaan dikendalikan menjual kepada perusahaan pengendali sebesar cost yang mengakibatkan pendapatan perusahaan yang dikendalikan menjadi rendah, dan laba perusahaan yang dikendalikan juga rendah sehingga kinerja keuangan perusahaan yang dikendalikan juga rendah. Hal ini akan berbeda ketika perusahaan yang dikendalikan menjual kepada pihak luar. Pendapatan yang diterima perusahaan yang dikendalikan akan lebih tinggi, sehingga laba perusahaan yang dikendalikan juga tinggi, yang kemudian akan berpengaruh pada kinerja keuangan perusahaan. Kinerja keuangan perusahaan yang dikendalikan akan lebih bagus ketika perusahaan yang dikendalikan menjual kepada pihak luar.

Hasil penelitian Keng et al. (2010) menemukan bahwa penjualan kepada pihak istimewa memiliki pengaruh positif signifikan terhadap kinerja keuangan perusahaan. Hasil ini menunjukkan bahwa semakin tinggi penjualan kepada pihak istimewa dilakukan, maka semakin bagus kinerja keuangan perusahaan penjual.

Penelitian yang dilakukan oleh Huang dan Liu (2010) memberikan hasil terdapat pengaruh negatif signifikan penjualan kepada pihak-pihak istimewa terhadap kinerja keuangan perusahaan. Hal ini berarti semakin sering perusahaan melakukan penjualan kepada pihak-pihak istimewa maka kinerja keuangan perusahaan semakin buruk.

Transaksi penjualan kepada pihak-pihak istimewa bersifat menguntungkan. Penjualan kepada pihak-pihak istimewa dapat mengurangi ketidakpastian dan biaya transaksi sehingga kinerja keuangan perusahaan bagus. Di lain sisi, penjualan kepada pihak-pihak istimewa juga dapat merugikan 
perusahaan ketika perusahaan itu dikendalikan. Berdasarkan uraian di atas, maka hipotesis pada penelitian ini adalah sebagai berikut:

\section{$H_{A .1}$ : Penjualan kepada pihak-pihak istimewa bepengaruh terhadap kinerja keuangan perusahaan.}

PSAK No. 7 (revisi 2009) menjelaskan bahwa pihak-pihak yang dianggap mempunyai hubungan istimewa bila satu pihak mempunyai kemampuan untuk mengendalikan pihak lain atau mempunyai pengaruh signifikan atas pihak lain dalam mengambil keputusan keuangan dan operasional. Transaksi pihak-pihak istimewa juga dapat diartikan sebagai suatu pengalihan sumber daya, jasa atau kewajiban antara entitas pelapor dengan pihak-pihak yang istimewa, terlepas apakah ada harga yang dibebankan.

Perusahaan akan lebih efisien ketika membeli barang dari pihak istimewa. Perusahaan tidak perlu membayar lebih, perusahaan tidak kesulitan dalam mencari mitra bisnis serta membandingkan harga. Hal ini akan mengurangi biaya dan juga waktu transaksi.

Perusahaan melakukan kontrak jangka panjang untuk menghindari risiko naiknya harga ketika perusahaan akan melakukan pembelian. Harga beli yang naik mengakibatkan laba yang diterima perusahaan pembeli menjadi rendah. Perusahaan yang telah melakukan kontrak jangka panjang akan membeli sebesar harga yang telah disetujui di dalam kontrak, sehingga laba perusahaan pembeli tetap stabil dan kinerja keuangan perusahaan pembeli masih bagus.

Perusahaan pengendali membeli barang dari perusahaan yang dikendalikan pada cost yang menyebabkan beban pokok penjualan perusahaan pengendali menjadi rendah saat perusahaan pengendali menjual kepada pihak luar. Hal ini akan berakibat pada laba yang diterima perusahaan pengendali menjadi lebih tinggi sehingga kinerja keuangan perusahaan pengendali meningkat.

Hasil penelitian Chen et al. (2009) menemukan bahwa pembelian dari pihakpihak istimewa berpengaruh positif signifikan terhadap kinerja keuangan perusahaan. Hal ini menunjukkan bahwa melalui pembelian dari pihak-pihak istimewa mampu meningkatkan kinerja pasar dan kinerja keuangan perusahaan.

Penelitian yang dilakukan oleh Lin et al. (2010) menemukan bahwa pembelian dari pihak-pihak istimewa berpengaruh secara negatif dan signifikan terhadap kinerja keuangan perusahaan.

Transaksi pembelian dari pihak-pihak istimewa dapat bersifat menguntungkan karena dapat mengurangi biaya dan waktu transaksi serta risiko di masa yang akan datang. Transaksi ini akan lebih efisien dan memiliki pengaruh yang bagus terhadap kinerja keuangan perusahaan. Di lain sisi, pembelian dari pihak-pihak istimewa juga dapat bersifat tidak menguntungkan kedua belah pihak. Pembelian dari pihak-pihak istimewa hanya menguntungkan bagi perusahaan pegendali saja. Hal ini disebabkan karena perusahaan pengendali memiliki kuasa untuk mengatur kebijakan. Berdasarkan uraian di atas, maka hipotesis pada penelitian ini adalah sebagai berikut:

\section{$H_{A .2}$ : Pembelian dari pihak-pihak istimewa bepengaruh terhadap kinerja keuangan perusahaan.}




\section{METODOLOGI PENELITIAN}

Penelitian ini menggunakan metode penelitian purposive sampling dengan kriteria sampel sebagai berikut:

1. Perusahaan manufaktur yang terdaftar di BEI dari tahun 2010 - 2012

2. Perusahaan melakukan transaksi penjualan kepada pihak-pihak hubungan istimewa atau transaksi pembelian dari pihak-pihak hubungan istimewa selama periode penelitian.

3. Perusahaan yang memiliki nilai outlier dikeluarkan dari sampel.

Tabel 1

Proses pemilihan sampel

\begin{tabular}{|l|l|l|l|l|}
\hline Kriteria Sampel & 2010 & 2011 & 2012 & Jumlah \\
\hline $\begin{array}{l}\text { Perusahaan manufaktur yang terdaftar } \\
\text { di BEI selama tahun 2010-2012 }\end{array}$ & 146 & 147 & 147 & 440 \\
\hline $\begin{array}{l}\text { Perusahaan yang tidak melakukan } \\
\text { transaksi penjualan atau pembelian kepada } \\
\text { pihak-pihak istimewa }\end{array}$ & $(47)$ & $(40)$ & $(41)$ & $(128)$ \\
\hline $\begin{array}{l}\text { Jumlah perusahaan yang melakukan } \\
\text { transaksi penjualan atau pembelian melalui } \\
\text { pihak-pihak istimewa }\end{array}$ & 99 & 107 & 106 & 312 \\
\hline $\begin{array}{l}\text { Jumlah perusahaan yang dikeluarkan } \\
\text { karena memiliki nilai outlier }\end{array}$ & $(28)$ & $(31)$ & $(29)$ & $(88)$ \\
\hline Jumlah sampel akhir & 71 & 76 & 77 & $\mathbf{2 2 4}$ \\
\hline
\end{tabular}

Variabel yang digunakan dalam penelitian ini yaitu:

$\mathrm{Y}_{\mathrm{it}}=\alpha+\beta_{1} \mathrm{RPTS}_{\mathrm{it}}+\beta_{2} \mathrm{RPTP}_{\mathrm{it}}+\mathrm{SIZE}_{\mathrm{it}}+\mathrm{LEV}_{\mathrm{it}}+\mathrm{GR}_{\mathrm{it}}+\varepsilon_{\mathrm{t}}$

Keterangan:

$\mathrm{Y}_{\mathrm{it}} \quad=$ ROA perusahaan $\mathrm{i}$ pada tahun $\mathrm{t}$ yang diukur dengan laba bersih dibagi total aset

$\alpha \quad=$ Bilangan konstan jika seluruh nilai independent adalah nol.

$\beta_{1} \quad=$ Koefisien regresi untuk penjualan kepada pihak-pihak istimewa

$\beta_{2} \quad=$ Koefisien regresi untuk pembelian dari pihak-pihak istimewa

RPTS $_{\text {it }}=$ Penjualan kepada pihak-pihak istimewa dibagi total penjualan perusahaan i pada tahun $\mathrm{t}$.

RPTP $_{\text {it }}=$ Pembelian dari pihak-pihak istimewa dibagi total beban pokok penjualan perusahaan i pada tahun $\mathrm{t}$.

$\mathrm{SIZE}_{\mathrm{it}}=$ Ukuran perusahaan $\mathrm{i}$ pada tahun $\mathrm{t}$ yang diukur dengan menggunakan Ln total aset

$\mathrm{LEV}_{\mathrm{it}}=$ Leverage perusahaan i pada tahun $\mathrm{t}$ yang diukur dengan membagi total liabilitas dengan total aset.

$\mathrm{GR}_{\mathrm{it}}=$ Growth revenue perusahaan i pada tahun $\mathrm{t}$ yang merupakan selisih pendapatan tahun ini dengan pendapatan sebelumnya dibagi dengan pendapatan sebelumnya.

$\varepsilon_{\mathrm{t}} \quad=$ residual error atau variabel pengganggu pada tahun $\mathrm{t}$. 


\section{Analisis Data dan Pembahasan}

1. Statistik Deskriptif

\section{Tabel 2}

\section{Hasil Statistik Deskriptif}

Descriptive Statistics

\begin{tabular}{|l|r|r|r|r|r|}
\hline & $\mathrm{N}$ & Minimum & Maximum & Mean & Std. Deviation \\
\hline RPTS & 224 & .00 & .74 & .1398 & .19289 \\
RPTP & 224 & .00 & .84 & .1304 & .18446 \\
ROA & 224 & -.12 & .40 & .0710 & .07565 \\
SIZE & 224 & 15.26 & 32.84 & 26.9657 & 3.27766 \\
LEV & 224 & .00 & 1.03 & .4820 & .20761 \\
GROWTH & 224 & -.40 & .72 & .1457 & .19483 \\
Valid N (listwise) & 224 & & & & \\
\hline
\end{tabular}

Penelitian ini menggunakan 224 perusahaan manufaktur yang terdaftar di BEI sebagai sampel penelitian. Nilai minimum dari RPTS adalah sebesar 0,00 yang menjelaskan terdapat beberapa perusahaan manufaktur di Indonesia yang tidak melakukan transaksi penjualan kepada pihak-pihak istimewa selama periode penelitian. Nilai maksimum dari RPTS yaitu sebesar 0,74 , nilai mean dari RPTS yaitu sebesar 0,1398 dengan standar deviasi sebesar 0,19289. Nilai mean sebesar 0,1398 menjelaskan bahwa rata-rata perusahaan manufaktur di Indonesia yang melakukan penjualan kepada pihak-pihak istimewa adalah sebesar 13,98\%.

Nilai minimum dari RPTP yaitu 0,00 . Hal ini serupa dengan RPTS dimana terdapat beberapa perusahaan manufaktur di Indonesia yang tidak melakukan transaksi pembelian melalui pihak-pihak istimewa. Nilai maksimum dari RPTP yaitu 0,84 dan nilai rata-rata atau nilai mean dari RPTP yaitu sebesar 0,1304 dengan standar deviasi sebesar 0,18446. Nilai mean dari RPTP sebesar 0,1304 menjelaskan bahwa rata-rata perusahaan manufaktur di Indonesia yang melakukan transaksi pembelian melalui pihak-pihak istimewa yaitu sebesar 13,04\%.

ROA memiliki nilai antara $-0,12$ sampai 0,40 dan nilai rata-rata sebesar 0,0710 dengan nilai standar deviasi sebesar 0,07565. Nilai ROA paling rendah yaitu -0,12 yang menunjukkan bahwa terdapat perusahaan yang mengalami kerugian karena memiliki nilai ROA negativ. Nilai ROA paling tinggi yaitu sebesar 0,40 atau $40 \%$ dengan rata-rata ROA perusahaan adalah sebesar 0,0710 atau setara dengan $7,10 \%$.

Size menunjukkan ukuran suatu perusahaan. Nilai size pada penelitian ini adalah sebesar 15,26 sampai dengan 32,84 dengan nilai rata-rata (mean) sebesar 26,9657 dan standar deviasi sebesar 3,27766. Size terbesar pada penelitian ini yaitu sebesar 32,84, sedangkan size terkecil pada penelitian ini yaitu 15,26.

Nilai Leverage (LEV) minimum adalah sebesar 0,00 yang menunjukkan bahwa terdapat perusahaan dengan risiko yang rendah. Nilai maximum leverage yaitu sebesar 1,03 yang menandakan terdapat perusahaan dengan risiko yang sangat tinggi karena memiliki rasio leverage sebesar 103\%. Nilai mean untuk leverage adalah sebesar 0,4820 dengan standar deviasi sebesar 0,20761 yang menunjukkan penyimpangan data pada penelitian ini. 
GROWTH menunjukkan pertumbuhan pendapatan suatu perusahaan. Nilai GROWTH pada penelitian ini berkisar antara -0,40 sampai dengan 0,72 dan juga memiliki nilai mean sebesar 0,1457 dengan nilai standar deviasi sebesar 0,19483. Dari nilai yang ada, dapat diketahui bahwa terdapat perusahaan yang tidak memiliki pertumbuhan pendapatan karena memiliki nilai GROWTH yang negatif dan juga terdapat perusahaan yang memiliki pertumbuhan pendapatan paling tinggi yaitu sebesar 0,72 atau setara dengan $72 \%$. Rata-rata pertumbuhan pendapatan perusahaan manufaktur di Indonesia adalah sebesar 14,57\%

\section{Uji Normalitas}

Uji Normlitas menggunakan uji Kolmogorov-Smirnov dengan kriteria nilai sig $>0,05$ maka data telah terdistribusi secara normal.

\section{Tabel 3}

Hasil Uji Normalitas

One-Sample Kolmogorov-Smirnov Test

\begin{tabular}{|c|c|c|}
\hline & & $\begin{array}{l}\text { Unstandardized } \\
\text { Residual }\end{array}$ \\
\hline N & & 224 \\
\hline \multirow[t]{2}{*}{ Normal Parameters ${ }^{\mathrm{a}}$} & Mean & .0000000 \\
\hline & Std. Deviation & .05836396 \\
\hline \multirow[t]{3}{*}{ Most Extreme Differences } & Absolute & .086 \\
\hline & Positive & .086 \\
\hline & Negative & -.060 \\
\hline Kolmogorov-Smirnov Z & & 1.281 \\
\hline Asymp. Sig. (2-tailed) & & .075 \\
\hline
\end{tabular}

3. Uji Asumsi Klasik

\subsection{Uji Multikolinearitas}

Uji mutikolinearitas dilakukan dengan melihat nilai VIF dan tolerance dengan kriteria nilai VIF lebih kecil dari 5 dan tolerance lebih besar dari 0,5 maka dapat dikatakan model regresi tidak terjadi persoalan multikolinearitas.

Hasil uji multikolinearitas yang telah dilakukan adalah sebagai berikut:

\section{Tabel 4}

Hasil Uji Multikolinearitas

\begin{tabular}{|c|c|c|c|}
\hline \multirow[b]{2}{*}{ Mode } & & \multicolumn{2}{|c|}{ Collinearity Statistics } \\
\hline & & Tolerance & VIF \\
\hline \multirow[t]{6}{*}{1} & (Constant) & & \\
\hline & RPTS & .912 & 1.096 \\
\hline & RPTP & .902 & 1.109 \\
\hline & SIZE & .938 & 1.066 \\
\hline & LEV & .971 & 1.030 \\
\hline & GROWTH & .964 & 1.037 \\
\hline
\end{tabular}

a. Dependent Variable: ROA 


\subsection{Uji Heteroskedastisitas}

Uji Heteroskedastisitas dilakukan dengan menggunakan uji Glejzer dengan kriteria jika nilai signifikansi antara variabel independen dengan absolut residual lebih dari 0,05 maka tidak terjadi masalah heteroskedastisitas.

Tabel 5

Hasil Uji Heteroskedastisitas

Coefficients $^{\mathrm{a}}$

\begin{tabular}{|c|c|c|c|c|c|}
\hline \multirow[b]{2}{*}{ Model } & \multicolumn{2}{|c|}{ Unstandardized Coefficients } & \multirow{2}{*}{$\begin{array}{c}\begin{array}{c}\text { Standardized } \\
\text { Coefficients }\end{array} \\
\text { Beta }\end{array}$} & \multirow[b]{2}{*}{$\mathrm{t}$} & \multirow[b]{2}{*}{ Sig. } \\
\hline & $B$ & Std. Error & & & \\
\hline 1 (Constant) & .080 & .025 & & 3.209 & .002 \\
\hline RPTS & -.016 & .015 & -.077 & -1.104 & .271 \\
\hline RPTP & .004 & .016 & .018 & .263 & .793 \\
\hline SIZE & .000 & .001 & -.075 & -1.088 & .278 \\
\hline LEV & -.020 & .013 & -.102 & -1.503 & .134 \\
\hline GROWTH & -.015 & .014 & -.073 & -1.076 & .283 \\
\hline
\end{tabular}

\subsection{Uji Autokorelasi}

Uji autokorelasi dilakukan dengan melihat nilai Durbin-Watson. Model dikatakan bebas dari masalah autokorelasi jika nilai Durbin-Watson terletak antara batas atas atau upper bound (du) dan (4-du), atau antara 1,81628 sampai 2,18372 .

\section{Tabel 6}

Hasil Uji Autokorelasi

\begin{tabular}{l|r|r|r|r|r|}
\hline Model & $\mathrm{R}$ & \multicolumn{1}{|c|}{ Model Summary $^{\mathrm{b}}$} \\
\hline 1 & $.636^{\mathrm{a}}$ & .405 & Adjusted R Square & $\begin{array}{c}\text { Std. Error of the } \\
\text { Estimate }\end{array}$ & Durbin-Watson \\
\hline
\end{tabular}
$\begin{aligned} & \text { a. Predictors: (Constant), GROWTH, RPTP, DEBT, SIZE, RPTS } \\
& \text { b. Dependent Variable: ROA }\end{aligned}$

\section{Analisis Regresi Linier Berganda}

Analisis regresi linier berganda digunakan untuk melakukan pengujian hipotesis dengan melihat nilai signifikansi. Jika nilai signifikansi $\leq 0,05$ maka hipotesis dalam penelitian ini diterima, sebaliknya jika nilai signifikansi $\geq$ 0,05 maka hipotesis dalam penelitian ini ditolak. Hasil uji hipotesis yang telah dilakukan adalah sebagai berikut: 
Tabel 7

Hasil Analisis Regresi Linier Berganda

Coefficients $^{\mathrm{a}}$

\begin{tabular}{|c|c|c|c|c|c|c|}
\hline & & \multicolumn{2}{|c|}{ Unstandardized Coefficients } & \multirow{2}{*}{$\begin{array}{c}\begin{array}{c}\text { Standardized } \\
\text { Coefficients }\end{array} \\
\text { Beta }\end{array}$} & \multirow[b]{2}{*}{$\mathrm{t}$} & \multirow[b]{2}{*}{ Sig. } \\
\hline \multicolumn{2}{|c|}{ Model } & B & Std. Error & & & \\
\hline \multirow[t]{6}{*}{1} & (Constant) & .100 & .036 & & 2.774 & .006 \\
\hline & RPTS & -.025 & .021 & -.065 & -1.185 & .237 \\
\hline & RPTP & .084 & .023 & .205 & 3.729 & .000 \\
\hline & SIZE & .002 & .001 & .092 & 1.698 & .091 \\
\hline & LEV & -.215 & .019 & -.589 & -11.108 & .000 \\
\hline & GROWTH & .067 & .021 & .172 & 3.225 & .001 \\
\hline
\end{tabular}

RPTS memiliki nilai sig $\geq 0,05$ sehingga penjualan kepada pihak-pihak istimewa tidak memiliki pengaruh signifikan terhadap kinerja keuangan

RPTP memiliki nilai sig $<0,05$ yaitu 0,000 sehingga pembelian dari pihakpihak istimewa berpengaruh secara signifikan terhadap kinerja keuangan.

Penjelasan pengaruh beberapa variabel kontrol adalah sebagai berikut:

a. Variabel ukuran perusahaan (SIZE) tidak berpengaruh signifikan terhadap kinerja keuangan perusahaan ( $\mathrm{sig}=0,091>0,05)$.

b. Variabel Leverage (LEV) berpengaruh negatif signifikan terhadap kinerja keuangan perusahaan $(\mathrm{sig}=0,00<0,05)$.

c. Variabel perubahan pendapatan (GROWTH) berpengaruh positif signifikan terhadap kinerja keuangan perusahaan $(\operatorname{sig}=0,01<0,05)$.

\section{Pembahasan}

Penjualan kepada pihak-pihak istimewa tidak berpengaruh signifikan terhadap kinerja keuangan perusahaan sehingga $\mathrm{H}_{1}$ pada penelitian ini tidak dapat diterima. Laba sebagai indkator kinerja keuangan suatu perusahaan bukan hanya diukur berdasarkan pendapatan yang diterima melalui hasil penjualan kepada pihak istimewa. Terdapat dua komponen untuk mengukur kinerja perusahaan yaitu pendapatan dan beban. Pendapatan yang tinggi tidak disertai dengan beban yang rendah akan membuat laba perusahaan menjadi rendah dan berakibat pada kinerja keuangan perusahaan menjadi buruk. Pendapatan yang rendah dan disertai dengan efisiensi dalam biaya akan menyebabkan kinerja keuangan perusahaan menjadi bagus. Oleh sebab itu penjualan kepada pihak-pihak istimewa tidak berpengaruh signifikan terhadap kinerja keuangan perusahaan. Hasil penelitian ini tidak konsisten dengan penelitian yang dilakukan oleh Huang dan Liu (2010) yang menemukan bahwa terdapat pengaruh negatif signifikan penjualan kepada pihak istimewa terhadap kinerja keuangan perusahaan. Hasil penelitian ini juga bertentangan dengan penelitian yang dilakukan oleh Keng et al. (2010) yang menemukan bahwa penjualan kepada pihak istimewa memiliki pengaruh positif signifikan terhadap kinerja keuangan perusahaan.

Pembelian dari pihak-pihak istimewa berpengaruh signifikan terhadap kinerja keuangan perusahaan sehingga $\mathrm{H}_{2}$ dalam penelitian ini dapat diterima. Perusahaan melakukan pembelian dari pihak-pihak istimewa, sehingga 
perusahaan dapat melakukan pengematan biaya dibandingkan dengan membeli dari pihak luar. Perusahaan dapat menghemat biaya sehingga beban perusahaan menjadi rendah yang akan diikuti dengan laba perusahaan yang tinggi, dan kinerja keuangan perusahaan pun yang bagus. Hasil penelitian ini sejalan dengan penelitian yang dilakukan oleh Chen et al. (2009) yang menemukan bahwa pembelian dari pihak-pihak istimewa memiliki pengaruh positif signifikan terhadap kinerja keuangan perusahaan.

\section{E. Kesimpulan dan Saran}

Dari hasil penelitian yang telah dilakukan, maka dapat ditarik kesimpulan sebagai berikut:

1. Penjualan kepada pihak-pihak istimewa tidak berpengaruh signifikan terhadap kinerja keuangan.

2. Pembelian dari pihak-pihak istimewa berpengaruh signifikan terhadap kinerja keuangan.

Keterbatasan dalam penelitian ini yaitu penelitian ini mengukur transaksi pihak-pihak istimewa hanya menggunakan penjualan kepada pihak-pihak istimewa dan pembelian dari pihak-pihak istimewa untuk melihat pengaruh transaksi pihak-pihak istimewa terhadap kinerja keuangan pada perusahaan manufaktur yang terdaftar di BEI. Penelitian selanjutnya dapat menggunakan pengukuran transaksi pihak-pihak istimewa lainnya yang telah diatur dalam PSAK No. 7 (revisi 2009), dan juga dapat menggunakan jenis industri lainnya yang kemudian disesuaikan dengan pengukuran sehingga pengaruh dari transaksi pihak-pihak istimewa ini lebih dapat dijelaskan lebih baik lagi.

\section{F. Daftar Pustaka}

Chen et al., (2009). The Impact of Related Party Transactions on the Operational Performance of Listed Companies in China. Taiwan: Department of Accounting, Soochow University.

Financial Accounting Standards Board, (1987). Statement Of Financial Accounting Concepts No. 1 Objective of Financial Reporting by Business Enterprises.

Hanafi, Mahfud.M. dan Abdul Halim. (2005). Analisis Laporan Keuangan edisi kedua. Yogyakarta: Unit Penerbit dan Percetakan AMP-YKPN.

Huang, T. dan Zhien-Chia Liu. (2010). A study of Relationship between Related Party Transactions and Firm Value in Technology Firms in Taiwan and China. African Journal of Business Management Vol,. 4 (9).

Ikatan Akuntan Indonesia. (2009). Pernyataan Standar Akuntansi Keuangan No. 7 (revisi 2009). Pengungkapan Pihak-Pihak yang Mempunyai Hubungan Istimewa. Jakarta: IAI.

Ikatan Akuntan Indonesia. (2012). Standar Akuntansi Keuangan Per 1 Juni 2012. Jakarta: IAI. 
Keng et al., (2010). Firm Performance and Related Party Sales Transaction: Evidence from Taiwan. Taiwan: Department of Accounting Information, Kun-Shan University.

Li, Pei-Chien. (2005). "The Relationship Between Firm Performance and Ownership structure, the Characteristic of Board, and the Related Party Transaction-The Examples of Electric Steel Industries in Taiwan". MA. Taiwan: Department and Graduate Institute of Finance, Chaoyang University of Technology.

Lee, dan Wu. (2012). To Verify How Ownership structures, Board of Director's Characteristic, Related-Party Transactions Upon The Operating Performance as Exemplified with Taiwan-Listed Info- Electronic Companies. Taiwan: Department of Marketing Management, Takming University of Science and Technology.

Pozzoli, Matteo and Marco Venuti. (2014). Related Party Transaction and Financial Performance: Is There a Correlation? Empirical Evidence from Italian Listed Companies. Open Journal of Accounting.

Widarjono, Agus. (2013). Ekonometrika Pengantar dan Aplikasinya Disertai dengan Panduan Eviews. Yogyakarta: UPP STIM YKPN. 